\title{
Utilisation of Mussel Shell Ash and Palm Oil Leaves Ash as Admixture in Concrete
}

\section{Muhammad Khairus Sholihin Bakar ${ }^{1}$, Nor Hazurina Othman ${ }^{1 *}$, Muhammad Shabery Sainudin $^{1}$, Faisal Sheikh Khalid ${ }^{1}$,Khairunisa Muthusamy ${ }^{2}$}

${ }^{1}$ Faculty of Civil Engineering and Built Environment,

Universiti Tun Hussein Onn Malaysia, 86400 Parit Raja, Johor, MALAYSIA

${ }^{2}$ Faculty of Civil Engineering and Earth Resources,

Universiti Malaysia Pahang, Lebuhraya Tun Razak, 26300 Kuantan, Pahang, MALAYSIA

*Corresponding Author

DOI: https://doi.org/10.30880/ijie.2020.12.08.030

Received 13 January 2020; Accepted 08 May 2020; Available online 15 September 2020

\begin{abstract}
Mussel shell and palm oil leaves is a type of waste that generally undergo disposal process due to lessvaluable materials. However, this waste is potentially to be used in concrete designing due to its cementing properties. Thus, this paper presenting the incorporation of mussel shell ash (MSA) and palm oil leaves ash (POLA) as an admixture in concrete. MSA and POLA were obtained through grounding, burning and sieving process. As total, 84 concrete samples were mixed with different proportions of POLA $(0.5 \%, 1 \%$ and $1.5 \%)$, MSA $(1 \%$ and $2 \%)$ and $\mathrm{K}$ for control samples. All the samples were cured for 7 days and 28 days. The study was carried out to measure its physical and mechanical properties such as compressive, split tensile and capillary absorption analysis. While, its materials properties (MSA and POLA) were identified through its specific gravity test. The results demonstrated that $\mathrm{B} 5(1.5 \%$ POLA $+1 \% \mathrm{MSA})$ gave a good performance in concrete compressive strength on 7 and 28 days. Besides that, B5 also indicates a lower capillary water absorption compared to other specimens. Whereas B6 indicates a higher value for density analysis. Overall, the experimental result indicates that B5 does not giving any adverse effect on the concrete performance. Thus, it is proved that the utilisation of MSA and POLA as cementing materials are applicable in improving concrete strength and its durability accordingly to the selected percentages.
\end{abstract}

Keywords: mussel shell ash, palm oil leaves ash, admixture, physical and durability

\section{Introduction}

Rapid urbanisation has the potential in improving of economical through its developments in various sector. This companion phenomena had contributed to the economy development and generates more income prospects. However, this has linked to environmental concerns which led to the increment of wastes being disposed from various sector. Thus, a significant action needs to be implemented in order to manage and control waste generated from the urbanisation activities in industrial or agricultural sector which could cause an environmental issue related to landfill and waste [1]. Regarding to this situation, this had drawn the attention among researcher in dispensing a research on the utilization waste generated from various sector as an eco-friendly material for new products.

Mussels or Perna viridis is a type of mollusc from fishery sector that were widely cultivated in Malaysia. This industry has a high demand and well received by the government in industry development. Department of Fisheries 
Malaysia issues statistics that mussel farmers were increases in every year and it had become one of country's economic resources. In year 2016, the quantity of mussel production had increased to 1,827.27 tonnes compared in year 2015 which are 1,673.27 tonnes [2]. The used of mussel shell in concrete to make concrete environmentally friendly by using natural waste material. The chemical composition of mussel shell makes it the same as the content contained in the limestone used ordinary Portland cement. It also plays a role as a filler in concrete and cement replacement materials [3].

There is other waste appeal among researchers such as palm trees or its scientific name, Elaeis guineensis is the most popular plants and the main economic resource of the country. Generally, Malaysia currently the world's secondlargest producer of palm oil [4]. In year 2017 the number of palm oil fruit production increased by 7,115,150 tonnes compared to $6,069,588$ tonnes in 2016 [5]. According to this statistic, it shows that Malaysia produces many wastes and not well utilized.

Palm oil fuel ash was produced from combustion of palm oil husk and palm oil shell. Palm oil fuel ash was dried in oven with a temperature of $110^{\circ} \mathrm{C}$ for 24 hours. The dried palm oil palm has facing a sieve process that passes over 300 $\mathrm{m}$ to ensure the removal of impurities and large particle size [6]. Table 1 shows the chemical composition on the mussel's shell, palm oil ash (POFA) and ordinary Portland cement.

Table 1 - Chemical composition of mussel shells, palm oil fuel ash (POFA) and ordinary Portland cement

\begin{tabular}{cccc}
\hline $\begin{array}{c}\text { Chemical } \\
\text { composition } \\
(\%)\end{array}$ & $\begin{array}{c}\text { Mussel shells } \\
\text { ash [3] }\end{array}$ & $\begin{array}{c}\text { Palm oil fuel ash } \\
\text { (POFA) [6] }\end{array}$ & $\begin{array}{c}\text { Ordinary } \\
\text { Portland } \\
\text { cement [3] }\end{array}$ \\
\hline $\mathrm{CaCO}_{3}$ & 95.6 & - & - \\
$\mathrm{SiO}_{2}$ & 0.73 & 49.20 & 21.20 \\
$\mathrm{Al}_{2} \mathrm{O}_{3}$ & 0.13 & 5.45 & 5.47 \\
$\mathrm{Fe}_{2} \mathrm{O}_{3}$ & 0.05 & 5.73 & 3.31 \\
$\mathrm{CaO}$ & 53.38 & 7.50 & 65.52 \\
$\mathrm{MgO}$ & 0.03 & 3.93 & 1.97 \\
$\mathrm{~K}_{2} \mathrm{O}$ & 0.02 & 5.30 & 1.71 \\
$\mathrm{Na}_{2} \mathrm{O}$ & 0.44 & 0.90 & 0.46 \\
$\mathrm{SO}$ & 0.34 & 1.73 & 1.90 \\
$\mathrm{Cl}_{3}$ & 0.02 & - & - \\
$\mathrm{SO}_{4}$ & 0.11 & - & - \\
$\mathrm{Lol}$ & - & 13.85 & - \\
$\mathrm{P}_{2} \mathrm{O}_{5}$ & - & 6.41 & \\
\hline
\end{tabular}

Various materials have been used to improve the properties of concrete with the change's technology. There are also many of kind waste materials such as shells, oyster shells, mussel shell and others waste which are used in concrete. Based on previous studies, palm oil fuel ash is a good material as a reactive as a pozzolan materials in concrete [7]. This shows that both admixtures have a lower weight of characteristic physical compared with ordinary Portland cement. The use of refined palm oil fuel ash will increase the concrete properties as well as potentially improve concrete performance [8]. Table 2 shows the use of various seashells and palm oil fuel ash (POFA) in the concrete.

Table 2 - The use of various shell and palm oil fuel ash (POFA) in concrete

\begin{tabular}{lcl}
\hline \multicolumn{1}{c}{ Researcher } & Materials & \multicolumn{1}{c}{ Results and Analysis } \\
\hline $\begin{array}{l}\text { Bin-yang et al. } \\
{[9]}\end{array}$ & Oyster shell & $\begin{array}{l}\text { Compressive strength: The optimum percentages use of oyster shells } \\
\text { in the mortar reaches } 49.2 \mathrm{MPa} \text { and the control mortar reaches } \\
46.9 \mathrm{Mpa}\end{array}$ \\
\hline $\begin{array}{l}\text { Gadgihalli et al. } \\
{[10]}\end{array}$ & Seashell & $\begin{array}{l}\text { Compressive strength: Concrete grade } 20 \text { and } 30 \text { achieved strength } \\
\text { of 20.3MPa and } 28.24 \mathrm{MPa} \text { and grade control concrete } 20 \text { and } 30 \\
\text { reached } 19.71 \mathrm{MPa} \text { and } 27.72 \mathrm{MPa} .\end{array}$ \\
\hline $\begin{array}{l}\text { Lertwattanaruk et } \\
\text { al. [11] }\end{array}$ & $\begin{array}{c}\text { Mussel } \\
\text { shell }\end{array}$ & $\begin{array}{l}\text { Specific gravity: The ordinary Portland cement is } 3.11 \text { and the } \\
\text { mussel shells is } 2.86 .\end{array}$ \\
\hline $\begin{array}{l}\text { Othman et al. } \\
{[12]}\end{array}$ & Shells & $\begin{array}{l}\text { Permeability of water: } 5 \% \text { mixture of shells ash } 11.30 \times\left(10^{-11}\right) \mathrm{m}^{2} \\
\text { while for normal concrete mixture } 28.50 \times\left(10^{-11}\right) \mathrm{m}^{2} .\end{array}$ \\
\hline $\begin{array}{l}\text { Namdar et al. } \\
{[13]}\end{array}$ & Seashell & $\begin{array}{l}\text { Compressive strength: The use of } 1 \% \text { ocean shell has the same } \\
\text { compressive strength as the control concrete of } 35 \mathrm{MPa} .\end{array}$ \\
\hline
\end{tabular}




\begin{tabular}{|c|c|c|}
\hline $\begin{array}{l}\text { Awal \& Shehu } \\
{[14]}\end{array}$ & POFA & $\begin{array}{l}\text { Specific gravity: The specific gravity of ordinary Portland cement is } \\
3.28 \text { and the specific gravity of oil palm husk ash is } 2.42 \text {. }\end{array}$ \\
\hline $\begin{array}{l}\text { Awal \& Nguong } \\
\text { [7] }\end{array}$ & POFA & $\begin{array}{l}\text { Compressive strength: The efficiency of POFA }(45 \mu \mathrm{m}) \text { increases } \\
\text { twice the compressive strength of } 39.5 \mathrm{~N} / \mathrm{mm}^{2} \text { and the crude POFA } \\
\text { reaches the compressive strength of } 19.5 \mathrm{~N} / \mathrm{mm}^{2} \text {. }\end{array}$ \\
\hline Shakir et al., [4] & POFA & $\begin{array}{l}\text { Compressive strength: The use of } 1 \%, 1.5 \%, 2 \% \text {, and } 2.5 \% \text { as } \\
\text { mortar additive for palm leaves reached } 16 \mathrm{MPa} \text { compressive } \\
\text { strength. }\end{array}$ \\
\hline $\begin{array}{l}\text { Rani \& } \\
\text { Tejaanvesh [15] }\end{array}$ & POFA & $\begin{array}{l}\text { Compressive strength: } 15 \% \text { POFA use as cement replacement } \\
\text { material in concrete increases compression strength of } 53.22 \mathrm{~N} / \mathrm{mm}^{2} \\
\text { compared to control concrete } 45.07 \mathrm{~N} / \mathrm{mm}^{2} \text {. }\end{array}$ \\
\hline
\end{tabular}

\section{Experimental Work}

\subsection{Materials}

\subsubsection{Palm oil leaves ash (POLA)}

Palm oil leaves that in this study was taken at Parit Hj. Rais, Parit Raja, Johor. Palm leaves were dried in temperature around $35^{\circ} \mathrm{C}$ and burned until turn as ash. After burned, sieve process will be done using a passing sieve $75 \mu \mathrm{m}$. Fig. 1 shows the POLA that used as admixture in concrete.

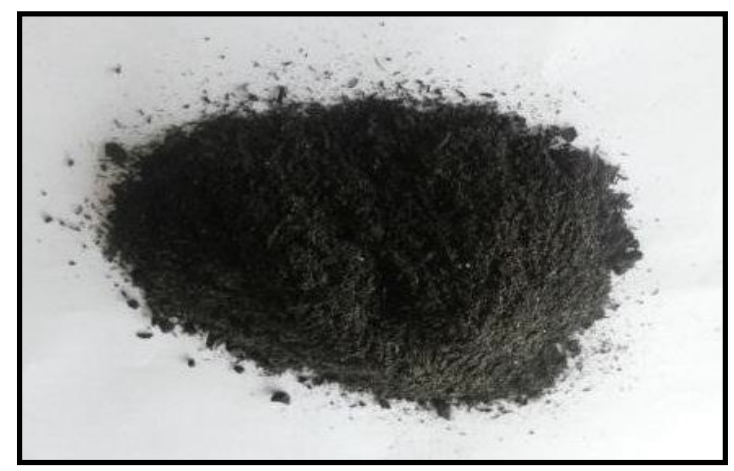

Fig. 1 - Palm oil leaves ash

\subsubsection{Mussel shell ash (MSA)}

Mussel shell used in this study was obtained from Pontian, Johor. Johor is the largest mussel's production with 1821.79 tonnes in 2016 [11]. The mussel has to be cleaned and dried at a temperature $35^{\circ} \mathrm{C}$ for one week. Next, mussel shells were blended using crusher machine (milling crusher machine) that passing sieve $5 \mathrm{~mm}$ and then continued crushing using ball mill (Los Angeles abrasion machine) to obtain the ash form that are passing $75 \mu \mathrm{m}$ sieve size. Fig. 2 shows the MSA that has passed through $75 \mu \mathrm{m}$ sieve.

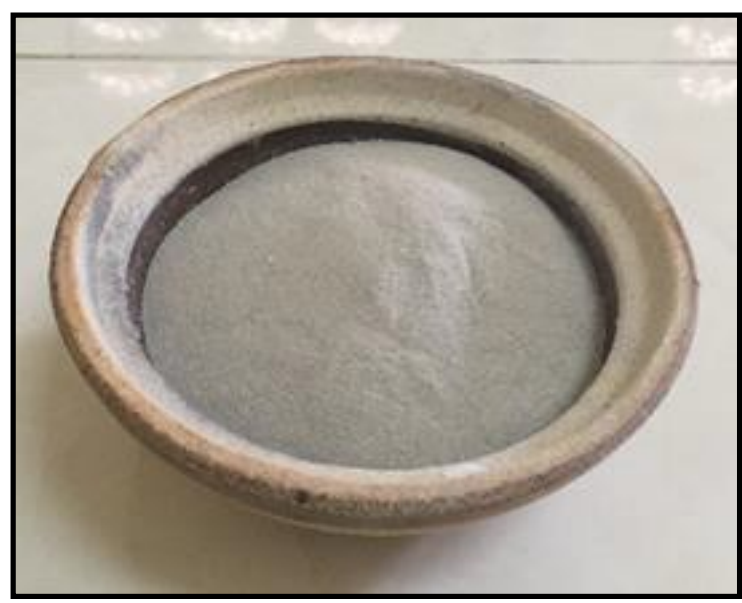

Fig. 2 - Mussel shells ash 


\subsubsection{Mix proportion}

Concrete mix was design according to DoE method with target concrete strength $30 \mathrm{MPa}$ at 28 days. Mixture of concrete with different mixtures of POLA $(0.5 \%, 1 \%, 1.5 \%)$ and MSA $(1 \%, 2 \%)$ were used as admixture in this study. The test samples were mixed from 7 different batches with the total number of 84 concrete cubes with size of $100 \mathrm{~mm} \mathrm{x}$ $100 \mathrm{~mm} \times 100 \mathrm{~mm}$. After that the samples were through the process of curing for 7 and 28 days to get the data and results of study. The results of control sample will be comparing with concrete sample with admixtures. Mix proportion as show in Table 3.

Table 3 - Mix proportion for specimen

\begin{tabular}{cccccc}
\hline Sample & $\begin{array}{c}\text { POLA } \\
(\mathbf{\%})\end{array}$ & $\begin{array}{c}\text { MSA } \\
(\%)\end{array}$ & $\begin{array}{c}\text { Cement } \\
\left(\mathbf{k g} / \mathbf{m}^{\mathbf{3}}\right)\end{array}$ & $\begin{array}{c}\text { Fine } \\
\text { aggregate } \\
\left(\mathbf{k g} / \mathbf{m}^{\mathbf{3}}\right)\end{array}$ & $\begin{array}{c}\text { Coarse } \\
\text { aggregate } \\
\left(\mathbf{k g} / \mathbf{m}^{\mathbf{3}}\right)\end{array}$ \\
\hline K & 0 & 0 & 360 & 630 & 1280 \\
B1 & 0.5 & 1 & 360 & 630 & 1280 \\
B2 & 0.5 & 2 & 360 & 630 & 1280 \\
B3 & 1 & 1 & 360 & 630 & 1280 \\
B4 & 1 & 2 & 360 & 630 & 1280 \\
B5 & 1.5 & 1 & 360 & 630 & 1280 \\
B6 & 1.5 & 2 & 360 & 630 & 1280 \\
\hline
\end{tabular}

\subsection{Testing Parameter}

\subsubsection{Specific gravity}

Specific gravity test is carried out to obtain its physical characteristics of POLA and MSA. The specific gravity is the mass ratio of the sample volume unit at a temperature specified with the same volume of distilled water at room temperature. POLA and MSA were tested according to BS EN 15326: 2007 + A1: 2009 BS 2000-549: 2007 [17].

\subsubsection{Slump}

Workability of concrete can be identified by concrete slump test and depends on cement-water ratio used in the concrete mix which is in this study value of cement-water ratio is 0.55 . However, excessive quantity of water could lead to bleeding which effecting the concrete strength [16]. The slump test was conducted in accordance with BS EN 12350-2: 2000 [18]. The ready-mix concrete was put into mould in 3 layers and each layer needs to be compacted using rods 25 times.

\subsubsection{Density}

Density test was conducted on wet concrete and dry concrete. Where wet concrete after the concrete curing process and dry concrete are put into the oven for one day at $105^{\circ} \mathrm{C}$. The data obtained in this test will be recorded for analysis. The standards used for this experiment are BS EN 12390-7: 2009 [19].

\subsubsection{Compressive strength test}

Concrete strength is one of important aspect and requirement that should well monitor in construction industry. One of common analysis to identified concrete strength are by compression test. In addition, the strength of concrete is affected when the preparation of concrete does not according to the standard testing. Size of samples for compressive strength test in this study are $100 \mathrm{~mm} \times 100 \mathrm{~mm} \times 100 \mathrm{~mm}$. Thus, the standard was used for this test is BS EN 12390-3: 2009 [20] to obtain the analysis.

\subsection{Capillary water absorption test}

The capillary absorption test was carried out to determine the absorption rate of the water into the concrete by measuring the weight of the concrete. This test is conducted according to the RILEM standards of CPC 11.2: 1982 [21]. The sample size of $100 \mathrm{~mm} \times 100 \mathrm{~mm} \times 100 \mathrm{~mm}$ are heated at $105^{\circ} \mathrm{C}$ in an oven for one day and let stand at room temperature for 6 hours. Only one surface of sample is exposed to water and before the samples put into water, it should be weighed first. In the last 5, 10, 20, 30, 60, 180, 360 and 1440 minutes need to be weighed as well as the rate of water absorption through its capillary absorption. Each admixture percentage is provided with 3 samples and the reading is taken on average. 


\section{Results and Discussion}

\subsection{Specific Gravity}

Based on the analysis, it shown that the specific gravity of OPC was higher comparing with POLA and MSA. Specific gravity of ordinary Portland cement is 3.33, meanwhile POLA is 2.05 and MSA is 2.49. Previous researcher found a similarity value were 2.52 [22,23]. While Garcia et al. [24] found that the value of MSA specific gravity was 2.62 and it showed slightly higher value compare in this study. However, the difference between previous researcher values of MSA and POLA are quite significant, those ash were still show it is lighter than ordinary Portland cement. Admixture material that are finer and lightweight will give advantage in concrete in terms of workability, density, capillaries and segregation [25]. Hence, specific gravity of POLA and MSA indicates that it is light and have potential as admixture and filler in concretes.

\subsection{Slump}

Result on slump test of concrete was presented as in Table 4. According to data collected in this study, control mix concrete has high workability compared to concrete containing admixtures. The slump value of control mix sample, $\mathrm{K}$ obtained slump value $55 \mathrm{~mm}$. While, sample concrete mixture B5 give a higher slump between other mixtures. However, it shows that B1 and B2 indicates similar slump value compared to other specimens. It is due less quantity of MSA and POLA that incorporated with cementing materials that causing almost the similar value for both mixes. According to Wen-Ten [26], utilisation of seashells in concrete potentially accelerates the cements hydration process due to high water absorption rates. The present of MSA and POLA might be the main causes that effecting to the slump value. Therefore, it is resulting low workability value compared to control sample.

Table 4 - Slump values from test

\begin{tabular}{cccc}
\hline Mixes & $\begin{array}{c}\text { Percent of admixtures (\%) } \\
\text { POLA }\end{array}$ & MSA & $\begin{array}{c}\text { Slump } \\
\text { (mm) }\end{array}$ \\
\hline Control sample (K) & 0 & 0 & 55 \\
B1 & 0.5 & 1 & 3 \\
B2 & 0.5 & 2 & 3 \\
B3 & 1 & 1 & 5 \\
B4 & 1 & 2 & 4 \\
B5 & 1.5 & 1 & 8 \\
B6 & 1.5 & 2 & 7 \\
\hline
\end{tabular}

\subsection{Density}

Density of concrete mixtures is indicated in Fig. 3. Overall, the density of concrete mixes is increased at 28 days curing compared to 7 days. Density of control concrete, $\mathrm{K}$ at the age of 28 days was $2310 \mathrm{~kg} / \mathrm{m}^{3}$ while the higher density of concrete containing admixture, B6 was is $2317 \mathrm{~kg} / \mathrm{m}^{3}$. This demonstrate that the more content of admixtures (POLA and MSA) give higher density. In the other words, it does not effects on the physical properties of concrete containing POLA and MSA.

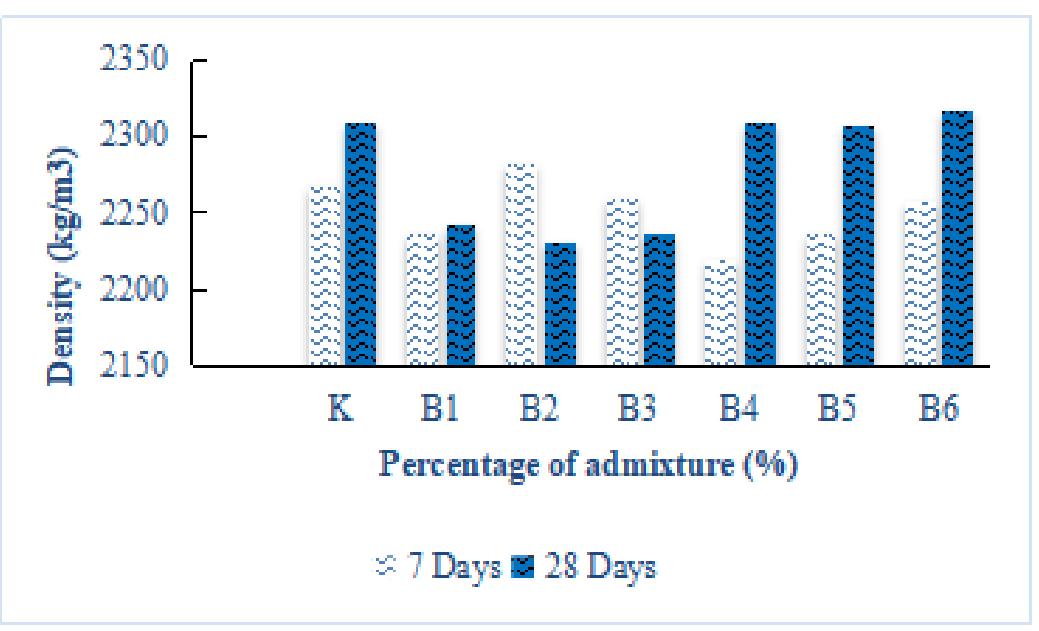

Fig. 3 - Density of concrete 


\subsection{Compressive Strength}

Fig. 4 shows the outcome in compressive strength for each specimen. Test results were determined based on average value of compressive strength to get on accurate reading. However, the compressive strength value all concrete with MSA and POLA mixture had exceeded the design target for specimens which is $30 \mathrm{MPa}$ at the age of 28 days. According to data obtained, the highest value noted by 1\% MSA and 1.5\% POLA replacement namely B5 (50 MPa). In short, this case happened due to the formation of four special minerals of chemical composition in cement namely alite, belite, trikalsium aluminat and tetrakalsium aluminoferat. When cement replaced with material like mussel shell ash and palm oil leaves ash, the total of alite with belite will brought out and cause CSH gel formed resultant the reduction both minerals in paste. This cause declination of concrete strength. Therefore, most researchers applied small replacement percentage so that product produced achieving goals without prepossess concrete strength worthless.

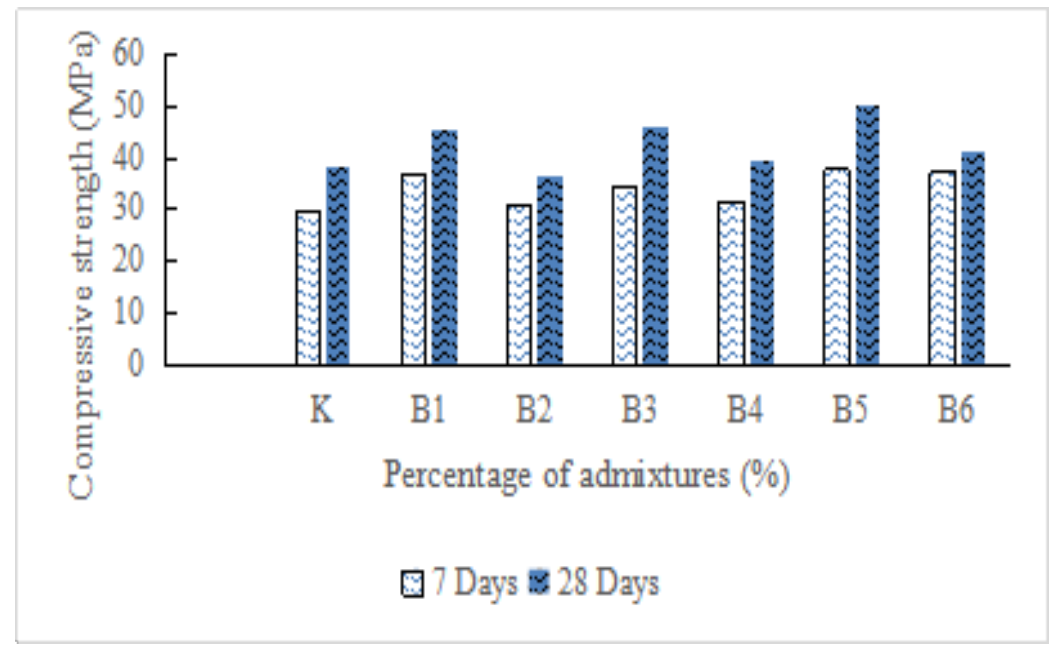

Fig. 4 - Compressive strength

\subsection{Capillary Water Absorption}

Fig. 5 shown the water capillary absorption against different percentage of admixtures for 42 samples. Overall, control sample, $\mathrm{K}$ has a high absorption rate $\left(3.50 \times 10^{-3} \mathrm{~cm} / \mathrm{s}\right)$ compared another mixture. According to the data obtained, concrete containing admixture provide low water absorption than control concrete, $\mathrm{K}$ at 28 days.

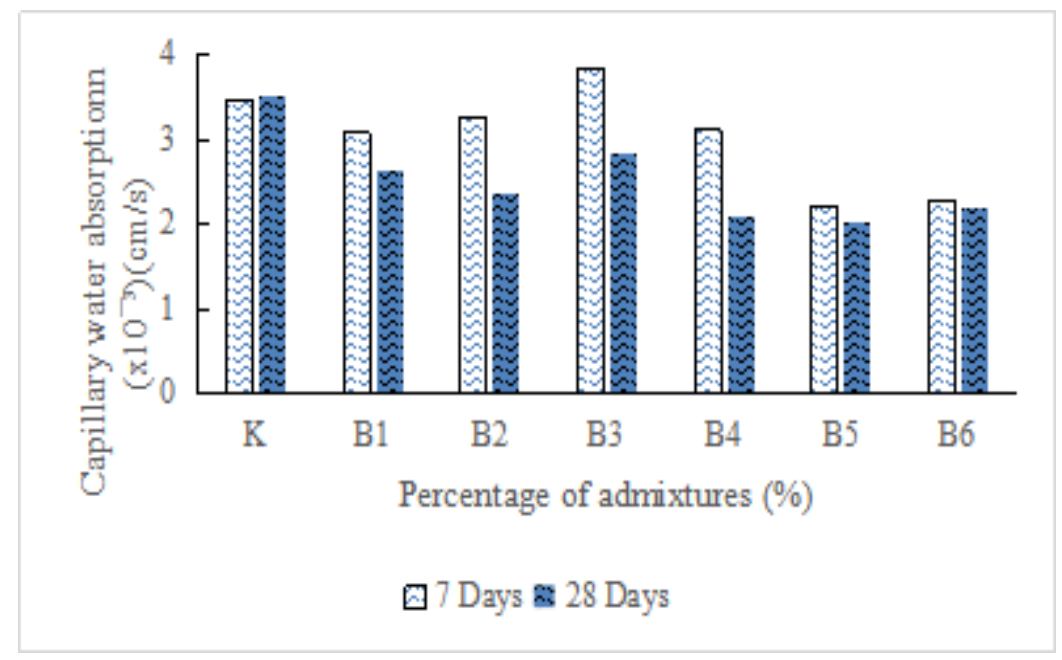

Fig. 5 - Capillary water values from various analysis

\section{Conclusion}

Based on experimental results, both admixtures of POLA and MSA have a lower water absorption through it capillary compared to control samples. These two admixtures potentially act as filler between cement and aggregate 
which causing less pores and void existing in internal concrete microstructure. Besides that, this experimental result also obtained that POLA and MSA are lighter compared to cement. Thus, a plenty of water is needed to moisten the entire surface particles of the POLA and MSA since the specific gravity lower than ordinary Portland cement because it will assist higher rate of hydration when both admixtures react with water.

According to compressive analysis, it shows the increment percentages of POLA improved concrete compressive strength compared to others samples. Whereas concrete on 28 days, specimens B5 had higher value of compressive compared to B6. It can clearly obtain that the increments of MSA percentages does not affecting on concrete mechanical properties. In other word, the utilisation of MSA are much less-effective compared to POLA materials. Overall, it was confirmed that the optimum percentage of admixtures selected was B5 with a mixture of $1.5 \%$ POLA and $1 \%$ of MSA. According to this percentages, it was significantly improving concrete performance in term of its strength and also permeability.

\section{Acknowledgement}

The authors would like to express gratitude in appreciate Universiti Tun Hussein Onn Malaysia for the financial (Geran Penyelidikan Pasca Siswazah -GPPS - H392) and all technical supports.

\section{References}

[1] Alireza, S., Ameri, F., Shoaei, P. and Bahrami, N. (2019). Recycled ceramic waste high strength concrete containing wollastonite particles and micro-silica: A comprehensive experimental study. Construction and Building Materials, 201, 11-32.

[2] Jabatan Perikanan Malaysia. (2016). Pengeluaran Akuakultur Mengikut Negeri dan Sistem Ternakan 2014,18 April, 2018 from https://www.dof.gov.my/.

[3] Wan Ahmad Soffian Bin Wan Mohammad, Nor Hazurina Othman, Mohd Haziman Wan Ibrahim, Masazurah A. Rahim, Shahiron Shahidan, and Raha Abd Rahman. (2017). A Review on Seashells Ash as Partial Cement Replacement. IOP Conference Series: Materials Science and Engineering 271 (1).

[4] Shakir, Alaa Ahmed, Karim Hadi Ibrahim and Ali Ahmed Mohammed. (2017). The Influence of Addition of Date Palm Leaves and Rice Husk on the Mechanical Properties of Cement Mortar, 2 (3): 95-99.

[5] Lembaga Minyak Sawit Malaysia. (2017). Pengeluaran Sawit 2017, 18 April, 2018 from https:// www.mpob.gov.my/.

[6] Awal, A S M Abdul and Siew Kiat Nguong. (2010). A Short-Term Investigation on High Volume Palm Oil Fuel Ash (POFA) Concrete. 35th Conference on Our World in Concrete \& Structures: 25 - 27 August 2010, Singapore.

[7] Abdul Awal, A. S M, and M. Warid Hussin (2011). Effect of Palm Oil Fuel Ash in Controlling Heat of Hydration of Concrete. Procedia Engineering 14: 2650-57.

[8] Maleka, Abdulmalik Musa, Ahmed Wsoo Hamad, and Ramadhansyah Putra Jaya. (2015). Effect of Palm Oil Fuel Ash (POFA) on the Durability of Asphaltic Concrete. Applied Mechanics and Materials 7: 1560-1565.

[9] Bin-yang, Zhong, Chan Chang-feng and Zhou Qiang. (2012). Structure and Property Characterization of Oyster Shell Cementing Material, Chinese J. Struct. Chem. 31: 85-92.

[10] Gadgihalli, Vishal, Raghavendra Prasad, Havanje Dinakar and Sharma. (2017). Analysis of Properties of Concrete Using Sea Shells 5: 374-78.

[11] Lertwattanaruk, Pusit, Natt Makul, dan Chalothorn Siripattarapravat. (2012). Utilization of Ground Waste Seashells in Cement Mortars for Masonry and Plastering. Journal of Environmental Management 111: $133-141$.

[12] Othman N H, Abu Bakar B H, Mat Don M and Megat Johari M A. (2013). Cockle Shell Ash Replacement for Cement and Filler in Concrete. Malaysian Journal of Civil Engineering 25 (2): 201-11.

[13] Namdar Abdoullah, Fadzil Mat Yahaya, Chua Pei Shan and Nabila Shahilla Rajagopal. (2014). Effect of Seashell Powder on Flexural and Compressive Strength of Cement Mortar in Early Age. Advanced Materials Research 894.

[14] Awal, A. S M Abdul and Shehu I A. (2013). Evaluation of Heat of Hydration of Concrete Containing High Volume Palm Oil Fuel Ash. Fuel 105: 728-31.

[15] Rani, M Swaroopa, and M Tejaanvesh. (2015). Performance of High-Strength Concrete Using Palm Oil Fuel Ash as Partial Cement Replacement 5 (4): 8-12.

[16] Sukesh Chandana, Katakam Bala Krishna, Psri Lakshmi Sai Teja and Skanakambara Rao. (2013). Partial Replacement of Sand with Quarry Dust in Concrete. International Journal of Innovative Technology and Exploring Engineering, 26: 2278-3075.

[17] British Standard Institution (1990). Bitumen and bituminous binders - Measurement of density and specific gravity - Capillary-stoppered pyknometer method. United Kingdom: BS EN 15326:2007+A1:2009 BS 2000549:2007.

[18] British Standard Institution (2000). Testing Fresh Concrete. Slump Test. United Kingdom: BS EN 12350-2:2000.

[19] British Standard Institution (2009). Density of hardened concrete. United Kingdom: BS EN 12390-7:2009. 
[20] British Standard Institution (2009). Compressive strength of test specimens. United Kingdom: BS EN 123903:2009.

[21] RILEM CPC 11.2 (1982). CPC 11.2 Absorption of Water by Concrete by Capillarity. CPC 11.2:1982.

[22] Ismail N, Othman N H, Inn G W and Sainuddin M S. (2019). Physical and Mechanical Properties of Concrete Containing Green Mussel (Perna viridis) Shell Ash as an admixture, Materials Science and Engineering 601:1234.

[23] Sainudin, M S, Othman N H,Wan Mohammad W A S, Wan IbrahimM H and Muthusamy K. (2019) Properties of Concrete Containing Mussel (Perna viridis) Shell Ash as Partial Cement Replacement. International Journal of Integrated Engineering. 11(9): 154-163.

[24] Garcia M C, Fonteboa B G, Abella F M and Lopez D C. (2017) Performance of Mussel Shell as Aggregate in Plain Concrete, Construction and Building Materials, 139, pp. 570-583.

[25] Neville A M and Brook J J. (2011). Properties of Concrete (Harlow, United Kingdom: Pearson Education Limited)

[26] Wen-Ten K., Wang H. Y., Shu C. Y. and Su D. S. (2013). Engineering Properties of Controlled Low-Strength Materials Containing Waste Oyster Shells. Construction and Building Materials 46: 128-133. 